\title{
Jakość złączy spawanych a bezpieczeństwo eksploatacji obiektów ciśnieniowych
}

\section{Quality of welded joints and safety of pressure vessels}

\section{Streszczenie}

W artykule omówiono zależność pomiędzy awariami stalowych konstrukcji ciśnieniowych a jakością złączy spawanych. Przedstawiono podstawowe nieprawidłowości zaobserwowane w procesach wytwarzania złączy spawanych. Przeprowadzono badania złącza wykonanego podczas remontu związanego $z$ wymianą opłomek w kotle parowym SR-25. Zniszczone złącze poddano badaniom laboratoryjnym w celu określenia wpływu jakości złącza na awarię kotła. Badania laboratoryjne wykazał liczne nieprawidłowości w technologii naprawy i przestrzegania procedur spawania.

\section{Wstęp}

Bezpieczeństwo eksploatacji urządzeń ciśnieniowych wykorzystywanych w energetyce zależy od wielu czynników. Spośród wszystkich urządzeń przetwarzających energię największe zagrożenie stwarzają kotły i rurociągi parowe. Do najistotniejszych czynników decydujących o bezpieczeństwie eksploatacji kotłów należy prawidłowe wyposażenie w osprzęt zabezpieczający przed nadmiernym wzrostem temperatury i ciśnienia, jak również okresowe kontrole oraz kwalifikacje i odpowiedzialność obsługi. O ile te czynniki w dużych firmach energetycznych są dość ściśle przestrzegane, o tyle $w$ małych i średnich przedsiębiorstwach produkujących gorącą wodę lub parę do celów technologicznych można stwierdzić wiele nieprawidłowości. Nie mniej istotnym czynnikiem decydującym o bezpieczeństwie eksploatacji jest jakość konstrukcji. W przypadku kotłów ciśnieniowych o jakości konstrukcji decyduje dobór materiałów konstrukcyjnych

Dr inż. Jan Stabryła, dr inż. Krzysztof Dutka - Uniwersytet Warmińsko-Mazurski w Olsztynie.

\section{Abstract}

The paper presents a dependence between breakdown of a steel pressure constructions and a quality of welded joints. The basic incorrectness observed in the welding technology are specified. Examination of welds performed in the repair and replacement of water tubes in the steam boiler SR-25 are performed. Destroyed weIded joint was laboratory tested to receive an answer to the question if a quality of weld had played any role in breakdown of a boiler. Examinations highlighted various shortcomings both in the technology of repair and compliance with procedure of welding.

i technologii wykonania. W produkcji zbiorników ciśnieniowych i rurociągów przesyłowych techniką łączenia jest spawanie, a o trwałości i niezawodności eksploatacyjnej konstrukcji decyduje jakość wykonanych złączy $[1 \div 4]$. W różnych dziedzinach wytwarzania podejście do jakości jest zróżnicowane $[2,5]$. Wytwarzanie i naprawa urządzeń ciśnieniowych podlega przepisom Urzędu Dozoru Technicznego (WUDT/UC/2003) [7] oraz Dyrektywie 97/23/WE Urządzenia ciśnieniowe i ich zespoły [8]. W firmach wytwarzających i remontujących spawane konstrukcje stalowe produkcja spawalnicza realizowana jest często w oparciu o uproszczona dokumentację konstrukcyjną prowadzoną bez nadzoru technicznego $[6,9,10]$. Również gospodarka materiałami podstawowymi i dodatkowymi, w tym: suszenie elektrod (metoda 111), przygotowanie i dopasowanie brzegów złączy nie zawsze realizowane jest zgodnie $z$ wytycznymi producentów. W firmach nierzadko brak jest technologów z zakresu spawalnictwa, a proces spawania realizowany jest według uznania spawacza, ustnych wskazówek brygadzisty lub mistrza - bez instrukcji WPS. Stwierdzono przypadki uzupełniania zbyt dużych odstępów pomiędzy łączonymi elementami za pomocą „wkładek” z pasków blachy lub prętów, a także przypadki, kiedy stale o podwyższonej 
wytrzymałości, np. 18G2A, o grubości elementów przekraczających $30 \mathrm{~mm}$, spawane były bez wstępnego podgrzewania [10, 11]. Do częstych nieprawidłowości należy również stosowanie materiałów bez atestu i bez sprawdzenia na rozwarstwienie. Brak wdrożenia systemu jakości wg normy PN-EN ISO 3834 oraz nieprzestrzeganie procedur wytwarzania i modernizacji konstrukcji spawanych zgodnie z przepisami dozoru skutkuje awariami złączy spawanych o różnej skali - od czasowego wyłączenia kotła z eksploatacji po wybuch. Opracowanie [12] dzieli uszkodzenia walczaka kotła na dwie grupy uszkodzeń: technologiczne/konstrukcyjne i eksploatacyjne.

Uszkodzenia powstałe podczas eksploatacji mogą wynikać z nieodpowiedniej obsługi i wad materiałowych oraz niezgodności spawalniczych złączy wytworzonych w produkcji lub naprawie. Wadliwe złącza, mimo że zawierają niezgodności spawalnicze, mogą być eksploatowane przez długi czas bazawaryjnie. Przykładem jest ujawnione w badaniach radiograficznych złącze rozgałęzienia rurociągu pary technologicznej pracujące bezawaryjnie przy ciśnieniu 2,5 MPa przez okres 30 lat (rys. 1). Wycięty fragment rozgałęzienia poddany badaniom VT i PT wykazał brak przetopu w grani, jak również siatkę powierzchniowych pęknięć zmęczeniowych materiału rur. Warto podkreślić, że jeżeli nieciągłość materiału nie ulega gwałtownemu powiększeniu, to mimo jej wielkości przekraczającej wymagany przepisami poziom, złącze może być eksploatowane przez długi okres. Taka sytuacja wymaga jednak stabilnej pracy obiektu i monitorowania. Przy wystąpieniu znacznego wzrostu temperatury lub ciśnienia - nieciągłości i karby mogą ulec gwałtownemu powiększeniu [5]. Ze względu na podatność do powiększania się niezgodności spawalniczych podczas pracy konstrukcji, można wyróżnić dwie kategorie niezgodności: przestrzenne - nietworzące karbu, ale zmniejszające przekrój użyteczny i płaskie, liniowe - tworzące karby.

Złącza spawane wykonywane podczas wytwarzania i remontu urządzeń ciśnieniowych muszą być kon-

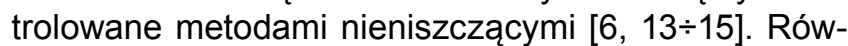
nież procesy degradacji materiałów i spoin zachodzące podczas eksploatacji wymagają okresowego monitorowania w zakresie powstawania i rozwoju niezgodności spawalniczych. Kontrola prac spawalniczych zarówno w trakcie, jak i po ich zakończeniu jest obowiązkiem służb nadzoru spawalniczego producenta urządzeń ciśnieniowych lub firmy remontowej. Wyeliminowanie groźnych niezgodności spawalniczych tworzących karby - zwłaszcza liniowych i płaskich typu przyklejenia, pęknięcia i braki przetopu, zabezpiecza w dużej mierze obiekt przed groźną awarią [5]. Dla bezpieczeństwa wymagane jest zagwarantowanie prawidłowości konstrukcji i eksploatacji.

Uszkodzenia kotłów zakwalifikowane w pracy [12] jako technologiczne są spowodowane rozwarstwieniem materiału ścianek oraz pęknięciem płaszcza przy spoinach króćców i wsporników. Uszkodzenia

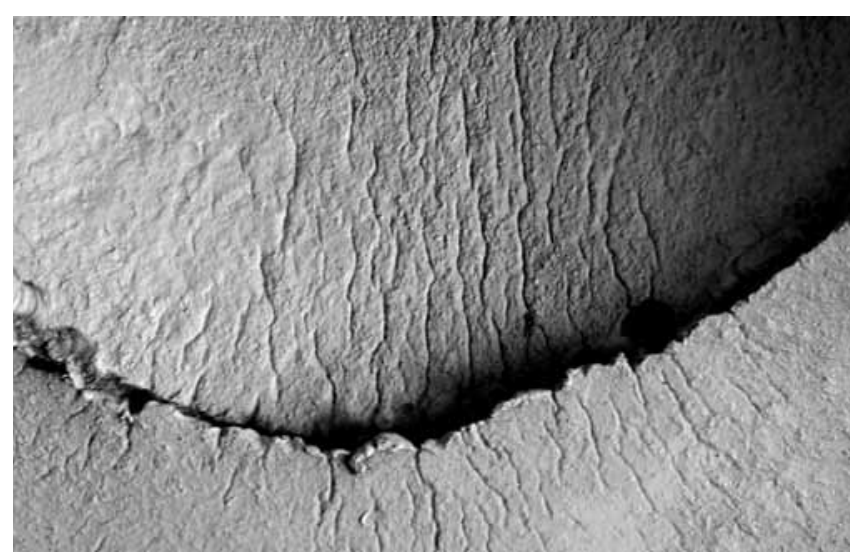

Rys. 1. Fragment rurociagu parowego. Widok od strony grani. Brak dopasowania, brak przetopu, siatka pęknięć ujawnionych w badaniach PT wywołanych zmęczeniem termicznym

Fig. 1. Fragment of a steam pipeline. View from the root side. Lack of fit, lack of fusion, net of cracks obtained in the heat-induced fatigue using PT testing method

eksploatacyjne związane są najczęściej z przegrzaniem płomienicy, szokiem termicznym, gwałtownym rozprężeniem przestrzeni wodno-parowej, korozją i zmęczeniem.

W przypadku spadku poziomu wody dochodzi do przegrzania płomienicy, płomieniówek lub opłomek. Elementy kotła ulegają wówczas przegrzaniu i uplastycznieniu. Dłuższe działanie wysokiej temperatury powoduje obniżenie $R_{e}$ i $R_{m}$, a co za tym idzie, odkształcenia i niekiedy utratę szczelności ścianek. W takim przypadku najbezpieczniejszym rozwiązaniem jest wygaszenie paleniska i wolne schładzanie kotła. Jeżeli przegrzany kocioł nie zostanie wolno schłodzony, a do przestrzeni pomiędzy walczakiem i płomienicą zostanie wprowadzona woda, następuje jej gwałtowne odparowanie. Nagły wzrost ciśnienia i fala uderzeniowa rozrywają przegrzaną i uplastycznioną ściankę płomienicy, płomieniówki lub opłomki. Przegrzaniu ścianki płomienicy może również sprzyjać powstanie grubej warstwy kamienia kotłowego przy stosowaniu nieuzdatnionej wody.

Najgroźniejszym przypadkiem awarii jest wybuch kotła. Siła wybuchu zależy od objętości przestrzeni wodno-parowej. Woda, która znajduje się w kotle, ma wysoką temperaturę i ciśnienie. Przy nagłym wypływie do atmosfery gwałtownie paruje i zwiększa swą objętość. Powstaje fala uderzeniowa w postaci wybuchu, który może nie tylko zniszczyć kocioł, ale również budynek kotłowni i zagrozić ludziom [4, 16].

Awaria kotła w każdym przypadku wymaga przeprowadzenia badań w celu wyjaśnienia przyczyn wystąpienia uszkodzenia. Jest to istotne ze względu na możliwość wykorzystania wniosków do podjęcia działań zapobiegawczych w innych podobnych obiektach. 


\section{Zakres badań}

Celem badań było określenie wpływu jakości spoiny naprawczej na wybuch kotła SR-25. Schemat kotła będącego przedmiotem badania przedstawiono na rysunku 2. Kocioł SR-25 jest konstrukcją pionową z płaszczem stalowym, wewnątrz którego znajduje się wbudowana płomienica o ściankach falistych. Płomienica ogrzewana jest przez spaliny wytwarzane na palenisku umieszczonym w jej dolnej części. Wewnątrz płomienicy znajdują się promieniście ułożone pionowe opłomki. Końcówki rur opłomkowych są połączone z zewnętrzną ścianą płomienicy spoinami obwodowymi. Przestrzeń pomiędzy płomienicą a płaszczem oraz wnętrze całej wysokości rur opłomkowych wypełnia woda, która po przegrzaniu zamienia się w parę. Para jest odbierana z górnej części przestrzeni roboczej kotła. Według dokumentacji kotła ciśnienie robocze wynosi 1,0 MPa. Płomienica wykonana jest ze stali St36K $(g=14 \mathrm{~mm})$, a dennica płaszcza ze stali St44K $(g=14 \mathrm{~mm})$. Kocioł typu SR-25 po trzynastoletniej eksploatacji w zakładzie przetwórstwa spożywczego wymagał wymiany opłomek usytuowanych wewnątrz płomienicy. Taka naprawa była związana z ich wycięciem, wymianą i pospawaniem złączami obwodowymi od strony przestrzeni wodno-parowej. Ze względu na brak dostępu do końców opłomek, płaszcz kotła został rozcięty obwodowo poniżej dolnego poziomu opłomek. Ponadto wycięto palnikiem gazowym złącze pomiędzy górną dennicą a płomienicą. Część górna odciętego płaszcza z dennicą została uniesiona. Po wymianie opłomek opuszczono płaszcz i obrócono o $200 \mathrm{~mm}$ w celu uniknięcia skrzyżowania spoin na złączu obwodowym pomiędzy jego górną i dolną częścią. Zarówno złącze na płaszczu, jak i pomiędzy płomienicą i dennicą wykonano metodą spawania łukowego elektrodą otuloną EB146. Ze względu na niewielką owalizację, płaszcz po obróceniu o $200 \mathrm{~mm}$ nie mógł być dokładnie dopasowany. Wykonane złącze miało przesuniętą ściankę. Spoinę płaszcza poddano badaniom ultradźwiękowym, na podstawie których dokonano odbioru prac spawalniczych i dopuszczono kocioł do eksploatacji. Kątowego złącza pomiędzy dennicą, a płomienicą nie badano. Prace przeprowadziła firma remontowa bez opracowania i zatwierdzenia dokumentacji technologii naprawy, jedynie w oparciu o ogólne technologie zakładowe. Prace spawalnicze wykonał spawacz bez aktualnych uprawnień. Zregenerowany kocioł pracował dalsze 7 lat.

W wyniku wybuchu zniszczeniu uległ kocioł i hala kotłowni. Zerwany został strop, dach i część walcowa komina ceglanego. Wygląd zniszczeń po wybuchu przedstawiono na rysunku 3. Podczas wstępnych oględzin stwierdzono: odchylenie kotła od pionu o ok. $7^{\circ}$, brak czopucha stalowego i zniszczenie złącza spawanego obwodowego (1 - rys. 2) pomiędzy dennicą a płomienicą. Górna część osłony izolacyjnej została zdemontowana. Na rysunku 4 przedstawiono widok uszkodzonego kotła od góry. O sile wybuchu świadczy fakt, że płomienica o grubości ścianki $14 \mathrm{~mm}$ przyjęła kształt cyfry 8 . Wewnątrz odkształconej na całej wysokości płomienicy zaciśnięte zostały opłomki.

$Z$ uszkodzonego kotła pobrano fragment obejmujący zarówno zniszczone, jak i nieuszkodzony odcinek złącza. Wygląd złącza na końcu pęknięcia przedstawiono na rysunku 5.

Do badań laboratoryjnych pobrano 3 fragmenty: A - złącze w przekroju uszkodzonym, B - złącze w przekroju nieuszkodzonym, C - fragment ścianki płomienicy o wymiarach $200 \times 300 \mathrm{~mm}$.

Badania laboratoryjne obejmowały:

- badania wizualne VT wg PN-EN 970,

- pomiary rozkładu twardości w złączu spawanym HV wg PN-EN 1043-1,

- pomiary wytrzymałości materiału płomienicy RM wg PN-EN 10002-1+AC1,

- badania makroskopowe MA i mikroskopowe MI złącza wg PN-EN 1321.

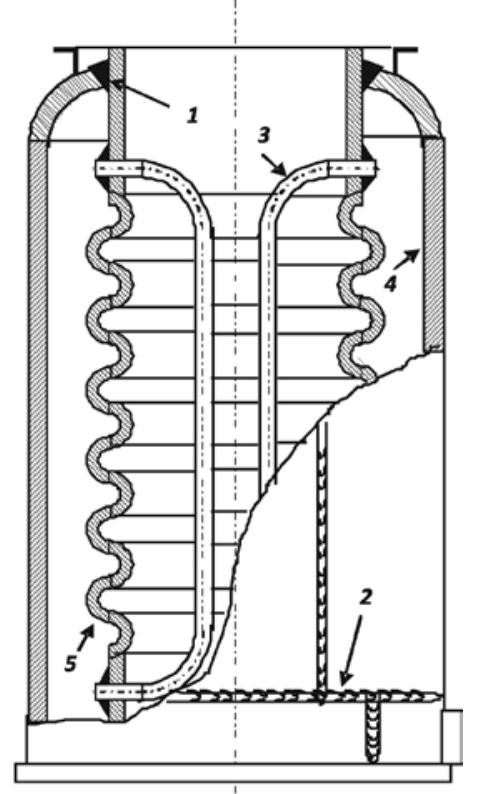

Rys. 2. Schemat kotła SR-25; 1,2 - spoiny naprawcze, 3 - opłomki, 4 płaszcz, 5 - płomienica Fig. 2. Schematic of the SR-25 boiler; 1, 2 - welds; 3 - water pipes; 4 -coat; 5 - flue tube

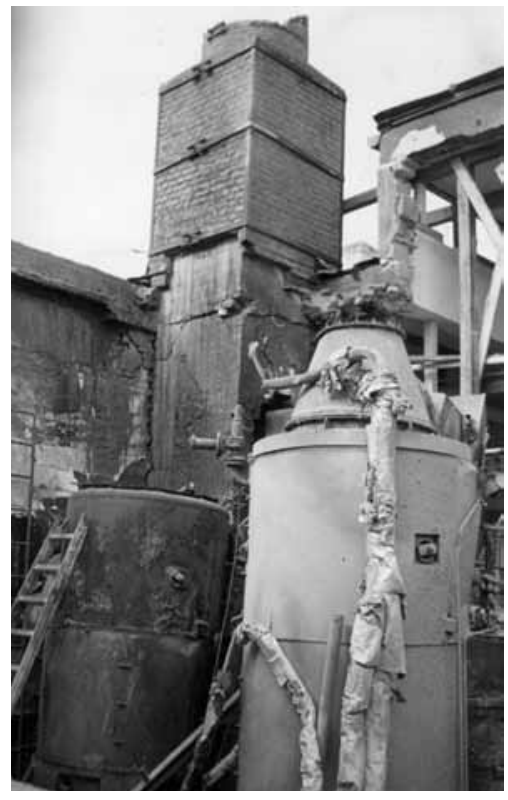

Rys. 3. Kocioł SR-25 po wybuchu. Widok zniszczonego kotła (z lewej) i budynku kotłowni

Fig. 3. SR-25 boiler after the explosion. View of the damaged boiler (left) and the boiler house 


\section{Badania wizualne}

Badania wizualne objęły ocenę jakości całego złącza na kotle oraz pobranego fragmentu.

Przełom spowodowany wybuchem rozerwał złącze na 2/3 obwodu, odrywając ściankę płomienicy (rys. 4). Pozostały 2 odcinki po ok. 300 mm spoiny, które nie zostały zniszczone i posłużyły do oceny jakości złącza. Ścianki płomienicy od strony wodnej pokryte są wżerami korozyjnymi i cienką warstwą kamienia kotłowego. $\mathrm{Na}$ końcu uszkodzonego złącza znajduje się rozwarstwiony i oderwany fragment ścianki płomienicy. Obserwując przełom stwierdzono, że na uszkodzonych odcinkach złącza występuje ciągły brak przetopu od strony grani (niezgodność 402 wg PN-EN ISO 6520-1). Czynny jasny przełom spoiny ma zmienną grubość na obwodzie wynoszącą $3 \div 7 \mathrm{~mm}$, co stanowi $22 \div 50 \%$ nominalnej grubości złącza. Przełom zawiera duże wtrącenia żużlowe (3012). Na pobranym do badań fragmencie złącza (rys. 5 i 6) widoczne są niezgodności typu: wklęśnięcie lica (511), podtopienie lica (5011), brak przetopu w grani (402) i wycieki grani (5041). Złącze nie spełnia wymogów poziomu jakości PJA B - wg PN-EN ISO 5817 wymaganego w urządzeniach ciśnieniowych.

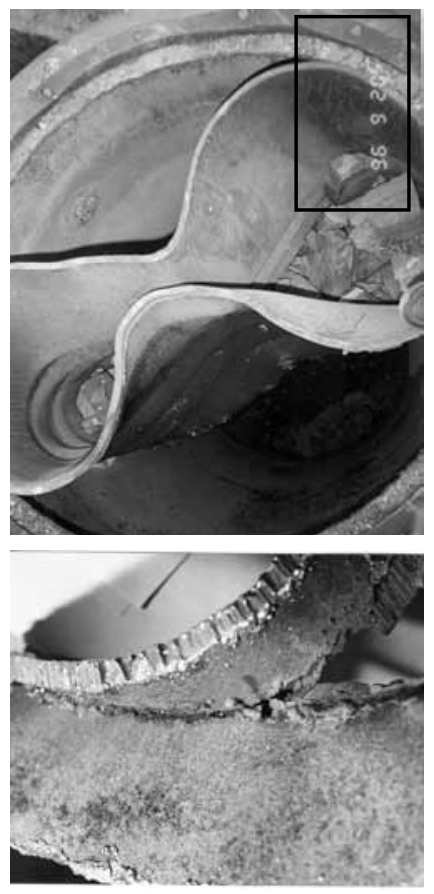

Rys. 4. Widok od góry na częściowo rozerwane złącze i zgniecioną wybuchem płomienicę. Miejsce pobrania materiału do badań laboratoryjnych

Fig. 4. View from the top of a partially broken joint and crumpled flue tube. Material sampling place for laboratory testing

Rys. 5. Fragment złącza pobranego do badań. Widok końca uszkodzenia od strony grani

Fig. 5. Sample of the joints taken for testing. View of damage from the end of the root of weld

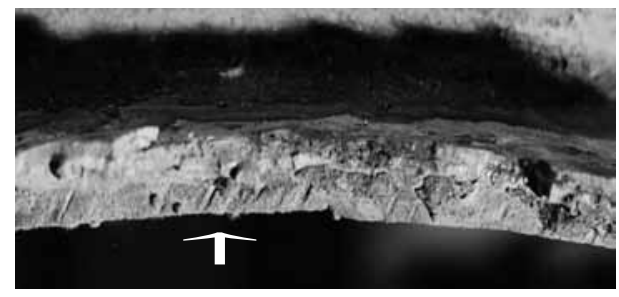

Rys. 6. Uszkodzone złącze. Na przełomie u dołu widoczny brak przetopu - ślady po szlifowaniu brzegów płomienicy przed spawaniem, w spoinie pojedyncze wtrącenia żużla

Fig. 6. Damaged joint. Bottom in the fracture lack of fusion - visible traces of grinding of the flue tube edges before welding, single slag inclusions in the weld

\section{Twardość}

Twardość HV10 zmierzono przy użyciu twardościomierza HPO 250 na przekroju poprzecznym odcinka B. Miejsca pomiaru lokalizowano w materiale rodzimym (MR) dennicy i płomienicy, strefie wpływu ciepła (SWC) oraz w spoinie, na głębokości do $2 \mathrm{~mm}$ pod powierzchnią lica. Wyniki badań zestawiono w tablicy I.

Najniższą twardość wykazuje materiał płomienicy - stal St36K. Materiał dennicy jest średnio o $9 \mathrm{HV}$ twardszy, co jest zrozumiałe, gdyż do jej wytworzenia użyto stali St44K. Strefy wpływu ciepła po obu stronach spoiny mają twardość porównywalną do materiałów rodzimych. Najwyższą twardość ma materiał spoiny

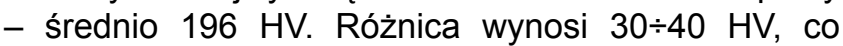
mieści się w granicach dopuszczalnej wartości różnicy twardości elementów złącza wynoszącej 100 HV. Maksymalna dopuszczalna twardość jest wyższa i wynosi $350 \mathrm{HV}$.

Tablica I. Twardość HV10 złącza

Table I. Results of HV10 hardness testing of the joint

\begin{tabular}{|c|c|c|c|c|}
\hline \multirow{2}{*}{ Miejsce pomiaru } & \multicolumn{4}{|c|}{ Numer pomiaru } \\
\cline { 2 - 5 } & $\mathrm{HV}_{1}$ & $\mathrm{HV}_{2}$ & $\mathrm{HV}_{3}$ & $\mathrm{HV}_{\text {sr }}$ \\
\hline MR dennicy & 160 & 168 & 161 & 163 \\
\hline MR płomienicy & 151 & 154 & 157 & 154 \\
\hline SWC dennicy & 165 & 165 & 168 & 166 \\
\hline Spoina & 195 & 196 & 197 & 196 \\
\hline SWC płomienicy & 149 & 155 & 155 & 157 \\
\hline
\end{tabular}

\section{Wytrzymałość mechaniczna}

Badaniom wytrzymałościowym poddano materiał płomienicy (próbkę C) jako elementu najbardziej narażonego na przegrzanie, a zatem na utratę właściwości wytrzymałościowych.

Próbę rozciągania materiału płomienicy przeprowadzono na próbkach płaskich 5-krotnych o przekroju $16 \times 14 \mathrm{~mm}$. Dwie próbki poddano próbie statycznego rozciągania na maszynie wytrzymałościowej ZDTe-30. Wyniki zamieszczone $w$ tablicy II porównano $z$ wymaganiami normy materiałowej dla stali St36K, z której została wykonana płomienica.

Tablica II. Wytrzymałość materiału płomienicy

Table II. The results of flue tube material strength

\begin{tabular}{|c|c|c|c|}
\hline Badany materiał & $R_{\mathrm{e}}, \mathrm{MPa}$ & $R_{m}, \mathrm{MPa}$ & $A_{5}, \%$ \\
\hline St36K wg PN-75/H-2123 & $\min .225$ & 355470 & $\min .20$ \\
\hline Fragment C - próbka 1 & 368 & 435 & 22,0 \\
\hline Fragment C - próbka 2 & 372 & 440 & 22,5 \\
\hline
\end{tabular}




\section{Badania makroskopowe i mikroskopowe}

Z fragmentów A i B wykonano próbki makroskopowe do oceny budowy złącza w miejscu zniszczenia spoiny i w miejscu nieuszkodzonym. Zgłady trawiono odczynnikiem Adlera. Na rysunku 7 przedstawiono złącze pęknięte całkowicie (1012) w miejscu połączenia spoiny z dennicą. Lico spoiny jest niewypełnione (511), materiał dennicy podtopiony (5011), a pomiędzy spoiną i płomienicą widoczna jest warstwa żużla.

Złącze przedstawione na rysunku 8 ma podobną budowę, chociaż nie uległo dekohezji. Uwagę zwracają ostre karby pomiędzy spoiną a łączonymi materiałami podstawowymi. Analiza makroskopowa ujawniła warstwę napawanego materiału na płomienicy. $W$ dolnej części napoiny znajduje się ciemne wtrącenie żużla (3012). Lico spoiny jest niewypełnione (511), brzeg dennicy z lewej strony podtopiony (5011), a grań spoiny jest przyklejona do napoiny na płomienicy (4013). Przy powiększeniu, oprócz niezgodności pochodzenia spawalniczego, zaobserwowano pionową linię ścinania adiabatycznego (rys. 9). Zjawisko to jest charakterystyczne dla materiałów odkształcanych z dużą prędkością (wybuchowo).

Badania mikrostruktury złącza wykonano przy użyciu mikroskopu metalograficznego OLYMPUS z cyfrowym zapisem obrazu. Badano strukturę materiału dennicy, spoiny i materiału płomienicy. Stwierdzono, że mikrostruktura płomienicy różni się od mikrostruktury dennicy kształtem ziaren. Materiał dennicy posiada strukturę ferrytyczno-perlityczną, podobnie jak materiał płomienicy (rys. 10, 11). Różnica polega na tym, że ferryt materiału dennicy ma ziarna drobne o układzie włóknistym, a materiał dennicy strukturę gruboziarnistego ferrytu o różnej orientacji. Struktury przedstawione na rysunkach 12 i 13 mają układ dendrytyczny wynikający z procesu krzepnięcia spoin. Dendryty lica

Rys. 7. Przekrój makroskopowy złącza w miejscu uszkodzonym (próbka A). Widoczne pęknięcie spoiny

Fig. 7. Macroscopic cross section of the joint in the place of damage (sample A). Visible fracture of the weld
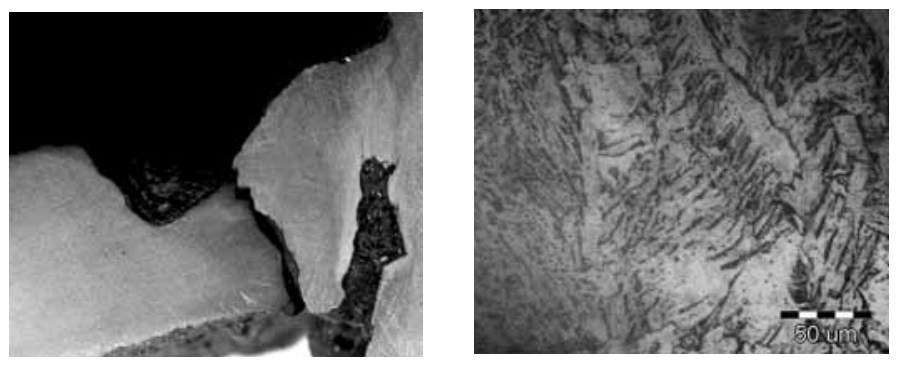

Rys. 10. Struktura dennicy. Pow. 200x, trawiono Nitalem. Pasmowa struktura ferrytyczno-perlityczna, wydłużone wtrącenia siarczkowe

Fig. 10. Bottom structure. Magn. 200x, Nital digested. Ferritic-pearlitic band structure, elongated sulfide inclusions

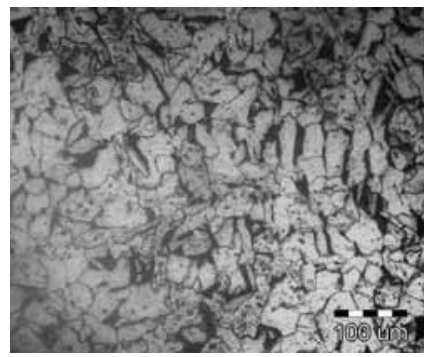

Rys. 11. Struktura płomienicy. Pow. 200, traw. Nitalem. Ziarnista struktura ferrytyczno-perlityczna, wtrącenia niemetaliczne Fig. 11. Flue tube structure. Magn. 200x, Nital digested. Grained ferritic-pearlitic structure, non-metallic inclusions
Rys. 12. Struktura lica spoiny. Pow. 500x, traw. Nitalem. Układ dendrytyczny

Fig. 12. The structure of the weld face. Magn. 500x, Nital digested. Dendritic arrangement
Rys. 8. Przekrój makroskopowy złącza w miejscu nieuszkodzonym (próbka B). Widoczna budowa złącza.

Fig. 8. Macroscopic cross section of the joint in the undamaged place (sample B). The visible structure of the joint.

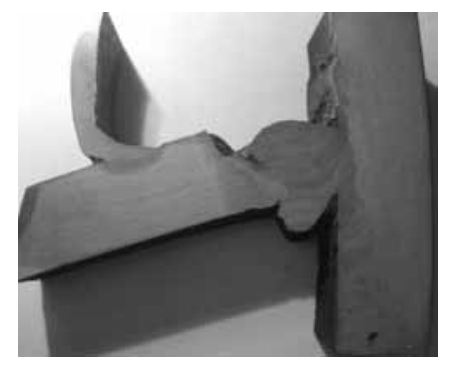

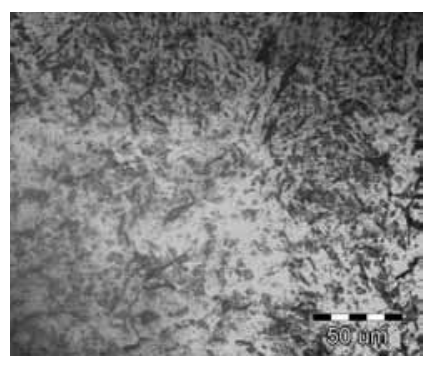

Rys. 13. Struktura napoiny płomienicy. Pow. 500x, traw. Nitalem

Fig. 13. The weld overlay structure of the flue tube. Magn. 500x, Nital digested 


\section{Wyniki badań}

Na podstawie bezpośrednich oględzin miejsca zdarzenia stwierdzono, że bezpośrednią przyczyną wybuchu kotła była dekompresja ciśnieniowa przestrzeni wodno-parowej. Pierwotna utrata szczelności spowodowała efekt gwałtownego odparowania wody i powstania fali uderzeniowej, która niszcząc złącze spawane $z$ dennicą, odkształciła symetrycznie płomienicę na całej wysokości. Kształt ósemkowy, jaki przyjął przekrój płomienicy, mógł być spowodowany jej owalizacją lub istniejącymi naprężeniami. Owalizację płaszcza stwierdzono już podczas wymiany opłomek. Przyczyną uszkodzenia nie mogło być obniżenie wytrzymałości podczas eksploatacji, gdyż mimo zmian strukturalnych wywołanych przegrzaniem, materiał płomienicy ma granicę plastyczności znacznie przekraczającą wartość minimalną $R_{\text {emin }}=225 \mathrm{MPa}$ wymaganą dla stali St36K. Wytrzymałość $R_{\text {mśr }}=437 \mathrm{MPa}$ mieści się $\mathrm{w}$ górnym zakresie wymagań. Rozkład twardości również nie wskazuje na wystąpienie nieprawidłowości. Średnia twardość materiału płomienicy wynosi $154 \mathrm{HV}$, a najwyższą twardość 196 HV ma spoina. Wynika $z$ tego, że dobór gatunku elektrody był prawidłowy.

Najwięcej zastrzeżeń budzi przekrój złącza. Porównując makrostrukturę dwóch przekrojów pobranych z miejsca uszkodzonego i nieuszkodzonego, można stwierdzić, że nie różnią się one w sposób zasadniczy. Oznacza to, że cały obwód złącza ma zbliżone niezgodności spawalnicze. Brak wypełnienia spoiny i pozostałe niezgodności obniżyły bardzo wytrzymałość złącza. Analiza przekrojów sprawia wrażenie, że układanie spoiny zostało niedokończone. Na przekroju makro są zbyt duże odstępy pomiędzy łączonymi elementami. Obecność warstwy napawanej sugeruje, że podczas wycinania spoiny na części obwodu nastąpiło wytopienie ścianki płomienicy na głębokość sięgającą połowy grubości ścianki. Obecność żużla na dnie napawanej warstwy świadczy o braku kontroli międzyoperacyjnej. Przepisy WUDT/UC/2003 wymagają dla złączy kątowych na urządzeniach ciśnieniowych wykonania spoiny z pełnym przetopem w poziomie jakości B. Stwierdzona na

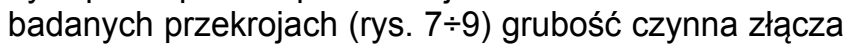
nie przekracza $5 \mathrm{~mm}$ przy grubości łączonych elementów $14 \mathrm{~mm}$. Na powierzchni czołowej zniszczonych odcinków spoiny zaobserwowano jeszcze mniejsze grubości czynne spoiny wynoszące nawet $3 \mathrm{~mm}$. Spoina o tak małej grubości pracowała przez 7 lat, gdyż była usztywniana przez prostopadłą do osi kotła ściankę dennicy.

Największym zagrożeniem dla wytrzymałości złącza była nie jego mała grubość, lecz karby i przyklejenia widoczne na przekroju poprzecznym. Na zgładzie makroskopowym przedstawionym na rysunku 9 widoczne są aż 4 takie koncentratory naprężeń w przekroju złącza. Cykliczne zmiany obciążenia powodowały rozwój karbów aż do wystąpienia pęknięć. Badania mikroskopowe pozwoliły jedynie stwierdzić różnicę $\mathrm{w}$ wielkości i układzie ziaren struktury płomienicy i dennicy. Udział fazowy ferrytu i perlitu jest zbliżony w obu materiałach. Różnica mikrostruktury dennicy i płomienicy mogła powstać podczas większego oddziaływania ciepła poprzez gorące spaliny oraz wcześniejszego wielokrotnego przegrzewania płomienicy. Dodatkowo badano strukturę spoiny i napoiny na płomienicy celem stwierdzenia, czy te elementy złącza uległy przegrzaniu wywołanemu brakiem wymaganego poziomu wody przed wybuchem. Wyrwanie fragmentu materiału ze ścianki płomienicy widoczne na końcu pęknięcia należy wiązać z miejscową wyższą wytrzymałością spoiny, na której pęknięcie zatrzymało się (rys. 6). Oderwany fragment ścianki ukazuje budowę włóknistą. Pęknięcie ścianki przebiega w połowie jej grubości w miejscu największego nasilenia siarczkowych wtrąceń niemetalicznych. Miejsce segregacji zostało dodatkowo osłabione przez przegrzanie podczas napawania.

\section{Wnioski}

Wybuch kotła należy łączyć jednoznacznie z niedopuszczalną jakością złącza wynikającą z niskich kwalifikacji spawacza oraz braku nadzoru spawalniczego ze strony firmy wykonującej prace remontowe. Nawet na podstawie kontroli wizualnej możliwe było zakwestionowanie jakości złącza.

W wyniku przeprowadzonych analiz i badań laboratoryjnych stwierdzono następujące nieprawidłowości w wykonaniu złącza kątowego dennica - płomienica:

- brak dokumentacji technologii naprawy kotła przy wymianie opłomek,

- nieprawidłową technikę wycinania złącza będącą powodem powstania miejscowych ubytków ścianki płomienicy,

- niewłaściwe przygotowanie elementów do spawania - za duży odstęp i próg lub brak ukosowania,
- brak nadzoru spawalniczego podczas wycinania spoiny, przygotowania złącza do powtórnego spawania i podczas spawania,

- brak zlecenia badań nieniszczących przez uprawnione laboratorium.

Wobec stwierdzonych niedociągnięć zaleca się w procesie organizacji prac i wykonywania złączy naprawczych kotłów i innych urządzeń ciśnieniowych:

- opracowywać szczegółową technologię naprawy, zatwierdzoną przez Inspektorat Dozoru Technicznego lub inną organizację dozorową,

- do prac spawalniczych zatrudniać spawacza o wymaganych i aktualnych kwalifikacjach,

- w procesach naprawy badać złącza próbne,

- stosować możliwe do wykonania badania nieniszczące podczas przygotowania do spawania, po spawaniu oraz monitorowanie złączy naprawczych podczas eksploatacji. 


\section{Literatura}

[1] Hernas A., Dobrzański J.: Trwałość i niszczenie elementów kotłów i turbin parowych. Wyd. Politechniki Śląskiej. Gliwice 2003.

[2] Robakowski T.: Wpływ wad w złączach spawanych na własności eksploatacyjne konstrukcji spawanych. Wydawnictwo Instytutu Spawalnictwa. Gliwice, 1997.

[3] Senkara J.: Czy złącze musi być najsłabszym miejscem konstrukcji. Biuletyn Instytutu Spawalnictwa, 5/2003

[4] Wajsyk K., Gucwa M., Gdański G.: Analiza przyczyn kruchego pękania przegrzewaczy pary pierwotnej. Przegląd Spawalnictwa, 11/2009.

[5] Saperski J., Wińcza M.: Jakość rzeczywista, czy jakoś tam będzie. Jakość prac spawalniczych, a problemy ekonomiczne wytwarzania. Przegląd Spawalnictwa, 11/2009.

[6] Wolak Z., Dutka K., Stabryła J., Lipiński T., Wach A.: Badania nieniszczące w ocenie stanu technicznego urządzeń energetycznych. Materiały Konferencji „Problemy eksploatacji maszyn w pracach wydziału mechanicznego”. Wydz. Mechaniczny ART w Olsztynie, Sekcja Podstaw Eksploatacji Komitetu Budowy Maszyn PAN. 1994.

[7] Warunki Urzędu Dozoru Technicznego WUDT/UC/2003 Urządzenia ciśnieniowe. Warszawa 2003.

[8] Dyrektywa 97/23/WE Urządzenia ciśnieniowe i ich zespoły. 2005.
[9] Dutka K., Stabryła J.: Jakość złączy w procesie wytwarzania i napraw konstrukcji spawanych. Konferencja Wydziału Mechanicznego „Doskonalenie techniki i technologii w przemyśle i rolnictwie". Olsztyn 1996.

[10] Stabryła J., Dutka K.: Analiza awarii konstrukcji spawanych. Przegląd Spawalnictwa, 6/2008.

[11] Ziółko J: Utrzymanie i modernizacja konstrukcji stalowych. Warszawa Arkady 1991.

[12] Zbroińska-Szczechura: Typowe uszkodzenia kotłowych walczaków. Dozór Techniczny, 4/2007.

[13] Lobanow L.M.: Current directions of research work conducted in the E.O. Paton Institute of Electric Welding in the field of welding technique and welded constructions strength. Biuletyn Instytutu Spawalnictwa w Gliwicach. R. 43, 5/1999, s. 17-19.

[14] Stabryła J.: Rola badań nieniszczacych w produkcji obiektów dla przemysłu spożywczego, VII Sympozjum im. Cz. Kanafojskiego „Problemy budowy oraz eksploatacji maszyn i urządzeń rolniczych. Płock 1997.

[15] Stabryła J.: Rola badań nieniszczących w zapobieganiu katastrofom ekologicznym. Sympozjum międzynarodowe „Ekologia w ogrodnictwie" Olsztyn 1996.

[16] Jakubiak A.: Uszkodzenia niemechaniczne urządzeń cieplnych elektrowni. WNT, Warszawa 1974.

\section{W następnym numerze}

\section{Jubileusz 60-lecia Zakładu Inżynierii Spajania Politechniki Warszawskiej}

Skrzyniecki Krzysztof, Kolasa Andrzej, Cegielski Paweł

Badanie charakterystyk statycznych i dynamicznych układu źródło zasilania - łuk w różnych metodach spawania

\section{Krajewski Arkadiusz}

Drgania mechaniczne w procesach spawalniczych

\section{Bober Mariusz}

Kompozytowe powłoki napawane plazmowo - charakterystyka i otrzymywanie

Tuz Lechosław, Kołodziejczak Paweł, Kolasa Andrzej

Struktura złączy doczołowych odlewniczych stopów magnezu

\section{Grześ Jarosław}

Warstwy pośrednie nakładane metodą tamponową

\section{Cegielski Paweł, Kolasa Andrzej, Sarnowski Tadeusz}

Programowe i sprzętowe metody dostosowania robotów do spawania łączonych elementów przy obniżonej dokładności

\section{Chmielewski Tomasz, Golański Dariusz}

Zastosowania spawalnicze w remanufakturingu

\section{Cegielski Paweł, Kolasa Andrzej, Sarnowski Tomasz, Oneksiak Arkadiusz}

Wdrożenia przemysłowe projektów badawczo-rozwojowych w zakresie mechanizacji i automatyzacji procesów spawalniczych 